\title{
Bozola Flap for Oral Cavity Reconstruction in Patients with Tongue Cancer
}

\author{
Ji Hye Kwak, Gil Joon Lee, Jin Ho Sohn, and Dongbin Ahn \\ Department of Otolaryngology-Head and Neck Surgery, School of Medicine, Kyungpook National University, Daegu, Korea
}

\author{
Bozola Flap을 이용한 설암 환자의 구강 재건술 \\ 곽지혜 · 이길준 · 손진호 · 안동빈 \\ 경북대학교 의과대학 이비인후-두경부외과학교실
}

\author{
Received March 25, 2018 \\ Revised June 10, 2018 \\ Accepted June 28, 2018 \\ Address for correspondence \\ Dongbin Ahn, MD \\ Department of Otolaryngology- \\ Head and Neck Surgery, \\ School of Medicine, \\ Kyungpook National University, \\ 130 Dongdeok-ro, Jung-gu, \\ Daegu 41944, Korea \\ Tel $+82-53-200-5781$ \\ Fax $+82-53-200-4524$ \\ E-mail godlikeu@naver.com
}

Background and Objectives The purpose of the present study was to evaluate the usefulness of a posterior-based buccinator myomucosal flap (the Bozola flap) for the reconstruction of oral cavity defects after tongue cancer resection.

Subjects and Method Fifteen patients who underwent from 2014 to 2016 reconstruction of the oral cavity with a Bozola flap after surgical management of tongue cancer were enrolled in the study. Patient characteristics, surgical outcomes, and complications associated with the Bozola flap were evaluated.

Results The flap was successfully harvested and transferred in all patients. The mean flap harvesting time was $25.3 \mathrm{~min}$. The donor site was closed primarily in 14 patients, and a buccal fat pad flap was used in one patient. Although partial necrosis of the flap occurred in two patients, no other major complications were noted.

Conclusion The results of this study demonstrate that the Bozola flap is a good option for reconstruction of moderate sized oral cavity defects in tongue cancer patients.

Korean J Otorhinolaryngol-Head Neck Surg 2018;61(11):605-10

Key Words Buccal mucosa - Flap · Reconstructive surgical procedures · Surgery · Tongue neoplasms.

\section{서 론}

지난 수십 년간 많은 두경부암, 특히 인두 및 후두암의 치료 에 있어 기관 보존(organ preservation)을 위한 항암 방사선 치료의 빈도가 점차 증가하고 있는 추세이나, 설암을 포함한 구강암에 있어서는 여전히 광범위한 수술적 절제가 일차 치 료로 인정받고 있다. ${ }^{1,2)}$ 이러한 설암의 수술적 절제에 있어서 는 충분한 변연을 확보하는 것이 가장 중요한 예후 인자 중 하 나인데, 이를 위해서는 적어도 육안적으로 확인되는 종양의 경계보다 $1.5 \mathrm{~cm}$ 가량의 추가적인 절제가 필요하며,4) 따라서

This is an Open Access article distributed under the terms of the Creative Commons Attribution Non-Commercial License (https://creativecommons.org/licenses/by-nc/4.0) which permits unrestricted non-commercial use, distribution, and reproduction in any medium, provided the original work is properly cited.
최종적인 구강설의 결손 범위는 실제 종양의 크기보다 상당 히 확장되게 된다. 이러한 이유로 원발암의 크기가 아주 작 은 경우를 제외하고는 대부분 결손의 크기와 위치에 따른 적 절한 재건술이 필요하게 된다. ${ }^{5)}$

최근 미세혈관 수술이 발달함에 따라 혀의 재건에 있어서 는 전완 유리 피판과 외측 대퇴 피판 등의 근막 피부 유리 피 판이 널리 이용되고 있다. ${ }^{6,7)}$ 이러한 유리 피판술은 큰 결손이 발생한 경우에도 충분한 용적을 제공할 수 있으며, 기능적인 측면에서도 비교적 양호한 연하 및 조음 기능을 보인다는 장 점을 가지고 있다. ${ }^{2,8)}$ 하지만 결손의 크기가 중등도인 구강의 결손에 있어서는 이러한 근막 피부 피판의 크기가 결손 크기 에 비해 다소 큰 경우가 있으며, 이러한 경우 피판을 통한 재 건이 오히려 남아있는 정상 구강설의 움직임을 저해하여 만 
족스러운 재건 결과를 낳지 못하는 경우가 흔히 발생한다. ${ }^{9)}$

최근 이와 같은 중등도 크기의 구강 재건에 있어 일차 봉합 이나 유리 피판의 대안으로 협부 피판(buccal flap)이 많은 관심을 모으고 있다. ${ }^{9,10)}$ 협부 피판은 피판의 조직 구성 측면 에서 협근 근점막 피판(buccinators myomucosal flap)으로 불리는데, 피판경(flap pedicle)의 위치에 따라 전방, 후방, 상 방, 하방으로 구분될 수 있으며, 피판경이 없는 도서형 피판 (island flap)의 형태로 사용할 수도 있다. ${ }^{10)}$ 이들 중 협부 동맥 으로부터 혈행 공급을 받는 후방 기저 협근 근점막 피판(posterior-based buccinators myomucosal flap)은 1989년 Bozola 등 ${ }^{11)}$ 에 의해 처음 기술되어 흔히 Bozola 피판으로 알려져 있 다. 해당 피판은 다양한 형태의 협근 근점막 피판 중 그 술기 가 가장 간단하고, 피판의 혈행을 담당하는 협부 동맥의 위 치가 거의 항상 일정하여 매우 안전한 피판이다. 하지만 현재 까지 대부분의 협근 근점막 피판에 대한 연구는 안면 동맥 을 공급 혈관으로 하는 안면 동맥 근점막 피판(facial artery myomucosal flap)에 집중되어 왔으며, Bozola 피판의 유용 성 및 결과에 대한 연구는 많이 부족한 실정이다. ${ }^{12-14)}$ 이에 저자들은 본 연구를 통해 구강설암 환자에 있어 Bozola 피판 의 기술적 가능성과 술 후 결과에 대해 알아보고자 하였다.

\section{대상 및 방법}

\section{대 상}

본 연구는 2014년 1월부터 2016년 6월까지 Bozola 피판을 이용해 구강 재건술을 시행한 15 명의 설암 환자를 대상으로 전향적으로 진행되었다(IRB No. 201805009002).

대상 환자의 평균 나이는 58.5세(20 87세)로 전체 15명 중 남자가 8명(53.3\%), 여자가 7명(46.7\%)이었다. 임상 병기는 TNM

Table 1. Baseline patient characteristics $(n=15)$

\begin{tabular}{lc}
\hline \multicolumn{1}{c}{ Characteristics } & No. of patients (\%) \\
\hline Age, years & $58.5(20-87)$ \\
Sex & $8(53.3)$ \\
$\quad$ Male & $7(46.7)$ \\
Female & \\
Dental status & $9(60.0)$ \\
Complete dentulous & $4(26.7)$ \\
Partial dentulous & $2(13.3)$ \\
Edentulous & $1(6.7)$ \\
T stage & $11(73.3)$ \\
T1 & $3(20.0)$ \\
T2 & $5.5(4.0-6.5) \times 4.1(3.0-5.0)$ \\
T3 & \\
Defect size (length $\times$ width), cm
\end{tabular}

Continuous data are presented as mean (range)
병기에 따라 T1NOMO인 경우가 1 예(6.7\%)였으며 T2NOMO인 경우가 11예(73.3\%), T3N0M0가 3예(20.0\%)였다(Table 1).

모든 환자는 수술 전 평가로 전이 여부를 확인하기 위한 초 음파 검사, 컴퓨터단층촬영, 자기공명영상촬영, 그리고 양전 자 방출 단층촬영술을 시행 받았으며, 이러한 영상 검사에서 전이가 확인된 경우는 본 연구에서 배제되었다. 설암의 치료 로는 모든 예에서 원발암의 육안적 경계로부터 $1.0 ~ 1.5 \mathrm{~cm}$ 를 포함하는 혀 부분 절제술과 함께 예방적 선택적 경부 절 제술(level I-III 또는 I-IV)이 시행되었다(Figs. 1 and 2).

\section{Bozola 피판의 수술 기법}

모든 수술은 전신마취하에 한 명의 두경부 외과의에 의해 시행되었으며 2.5 배 확대경을 착용한 직접 시야에서 진행되 었다. 피판의 크기는 과교정 없이 결손의 크기와 거의 동일하 게 도안하였으며, 피판 거상시 이하선관의 개구부를 손상시키 지 않도록 주의하였다. 피판의 전방 경계는 협교련(oral commissure)으로부터 최소 $1 \mathrm{~cm}$ 후방이 되도록, 후방으로는 익 돌하악봉선(pterygomandibular raphe)이 되도록 하였다. 또

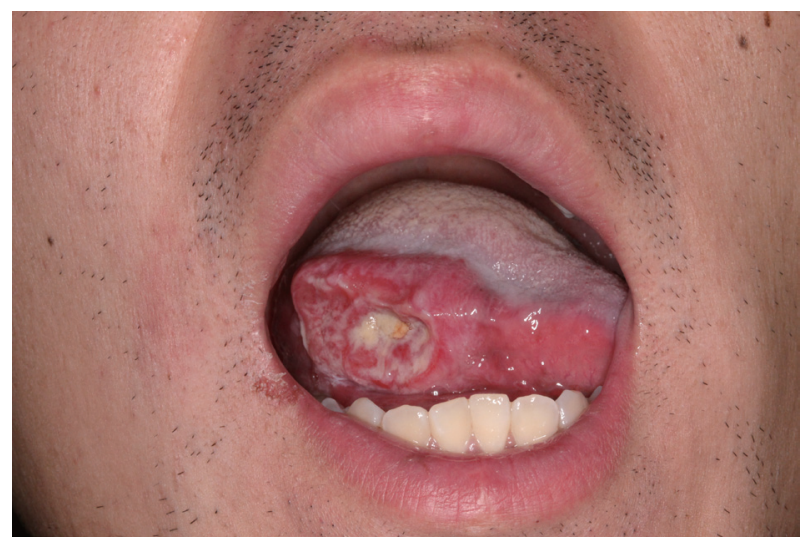

Fig. 1. Preoperative photograph showing an ulcerofungative mass in the right side of the tongue extending into the floor of mouth.

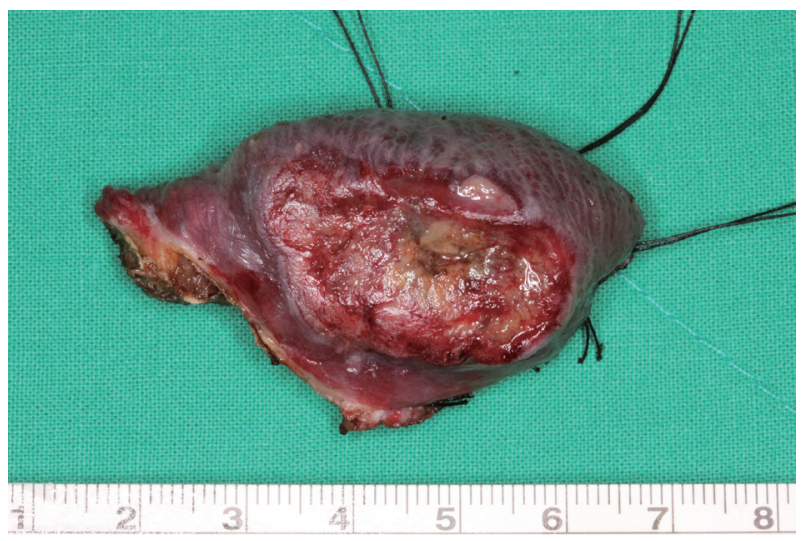

Fig. 2. Partial glossectomy was performed with sufficient resection margin. The specimen size was approximately $5.5 \times 3.5 \mathrm{~cm}$. 
한 피판의 폭은 가능한 한 $3.5 \mathrm{~cm}$ 을 넘지 않도록 하여 공여 부의 일차 봉합이 가능토록 하였다. 협부 점막과 협근을 절 개하고 협근과 협부 인두근막 사이의 층을 따라 전방에서 후방을 향해 피판을 거상하였다. 익돌하악봉선 바로 전방에 는 협부 동맥을 포함한 피판의 혈관경(vascular pedicle)을 확 인하고자 하였으며, 이후 거상된 피판은 과도한 꼬임이 생기 지 않도록 주의를 기울이며 결손부로 회전시켜 봉합하였다 (Fig. 3)

\section{평가 항목}

수술 전 환자의 나이와 성별, 치아 상태, 원발병소의 임상 병기를 평가하였다. 수술 중 원발병소 제거에 따른 결손의 크 기, 피판의 크기, 피판 거상에 걸리는 시간, 피판 혈관경의 확 인 여부, 공여부의 재건법을 조사하였으며 이차 수술로 피판 경 절개술을 시행하였는지 또한 확인하였다. 수술 후 피판과 관련한 합병증을 평가하기 위해 혈종의 발생 여부와, 피판의 괴사 등에 대해 확인하였으며, 술 후 3개월 경 구강 열림 제한 (maximal interincisal opening) 및 협교련의 비대칭 여부 등

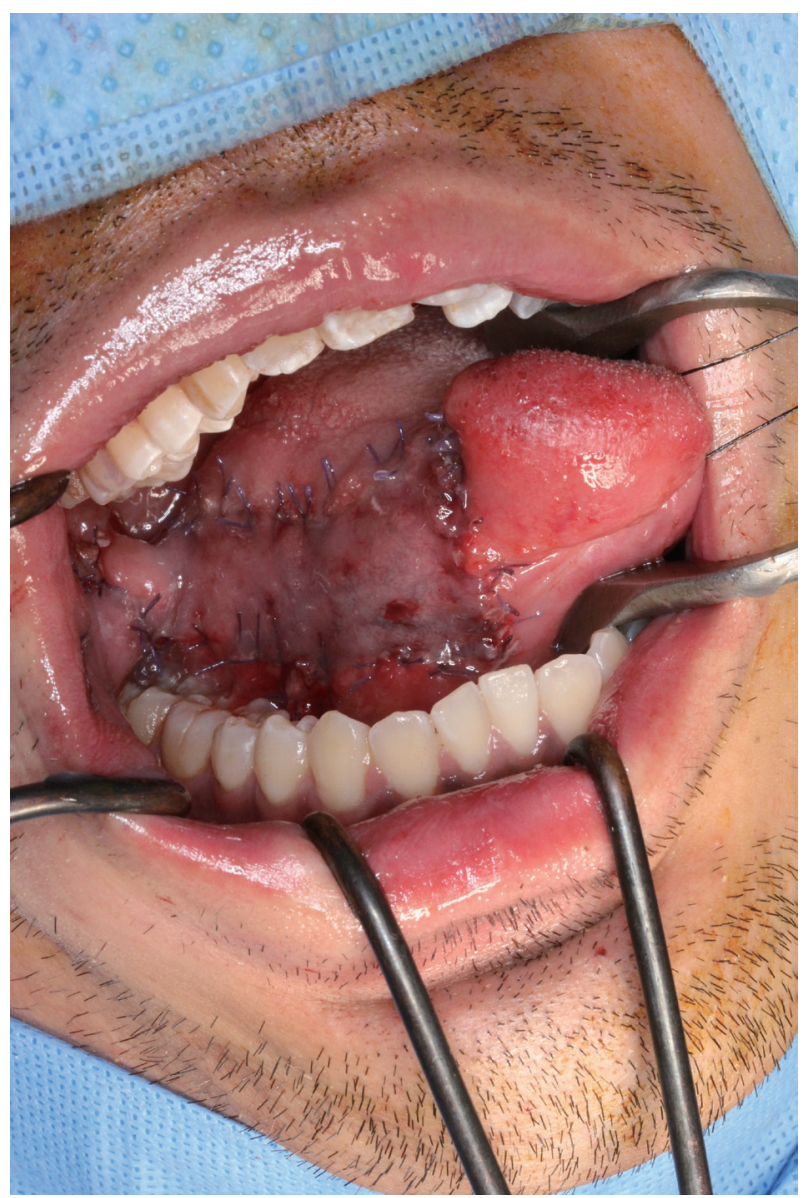

Fig. 3. The Bozola flap was elevated and sutured to the residual tongue without excessive twisting of the pedicle.
에 대해 평가하였다.

\section{결 과}

\section{수술 결과}

원발암 절제 후 결손부의 평균 크기는 5.5(4.0 6.5 cm)× $4.1 \mathrm{~cm}(3.0 \sim 5.0 \mathrm{~cm})$ 였고, 피판의 평균 크기는 5.2(4.0 6.0 $\mathrm{cm}) \times 3.4 \mathrm{~cm}(3.0 \sim 4.5 \mathrm{~cm})$ 이었다. 피판 거상에 걸린 평균 시 간은 25.3분(20 35분)이었으며, 12 예(80\%)에서는 피판 거상 중 협부 동맥 혈관경을 확인할 수 있었으나, 3예(20.0\%)에서 는 혈관경의 직접적인 확인 없이, 혈관경이 위치하는 조직층 을 포함하여 피판을 거상하였다. 협부 공여부의 결손은 14 예 (93.3\%)에서 일차 봉합으로, 1 예에서는 협부 지방패드(fat $\mathrm{pad)}$ 피판을 이용하여 재건하였다. Bozola 피판을 이용한 구 강 재건 이후 이차 수술로 피판경을 절단해야 했던 경우는 모 두 10예(66.7\%)로, 치아에 피판경이 씹히거나 치아 보철물 사 용에 장애가 되어 시행되었다(Table 2).

\section{수술 후 합병증}

전체 15 명의 환자 중 수술 후 공여부 또는 수혜부에 혈종 이 발생한 경우는 1 예도 없었다. 2 예(26.7\%)에서 피판의 변연

Table 2. Results of buccinator myomucosal flap $(n=15)$

\begin{tabular}{lc}
\hline \multicolumn{1}{c}{ Variables } & No. of patients $(\%)$ \\
\hline Flap size (length $\times$ width), cm & $5.2(4.0-6.0) \times 3.4(3.0-4.5)$ \\
Flap harvest time, min & $25.3(20-35)$ \\
Identification of vascular pedicle & $12(80.0)$ \\
Yes & $3(20.0)$ \\
No & $14(93.3)$ \\
Donor site closure & $1(6.7)$ \\
Primary closure & $10(66.7)$ \\
Buccal fat pad flap & \\
Second stage pedicle section &
\end{tabular}

Continuous data are presented as mean (range)

Table 3. Complications associated with buccinator myomucosal flap $(n=15)$

\begin{tabular}{|c|c|}
\hline Variables & No. of patients (\%) \\
\hline Donor site hematoma & $0(0.0)$ \\
\hline \multicolumn{2}{|l|}{ Flap necrosis } \\
\hline Partial & $2(13.3)$ \\
\hline Complete & $0(0.0)$ \\
\hline \multicolumn{2}{|c|}{$\begin{array}{l}\text { Limitation of mouth opening } \\
\text { (maximal interincisal opening), mm }\end{array}$} \\
\hline Minimal (30-35) & $2(13.3)$ \\
\hline Moderate (15-30) & $0(0.0)$ \\
\hline Severe $(\leq 15)$ & $0(0.0)$ \\
\hline Oral commissure asymmetry & $0(0.0)$ \\
\hline
\end{tabular}




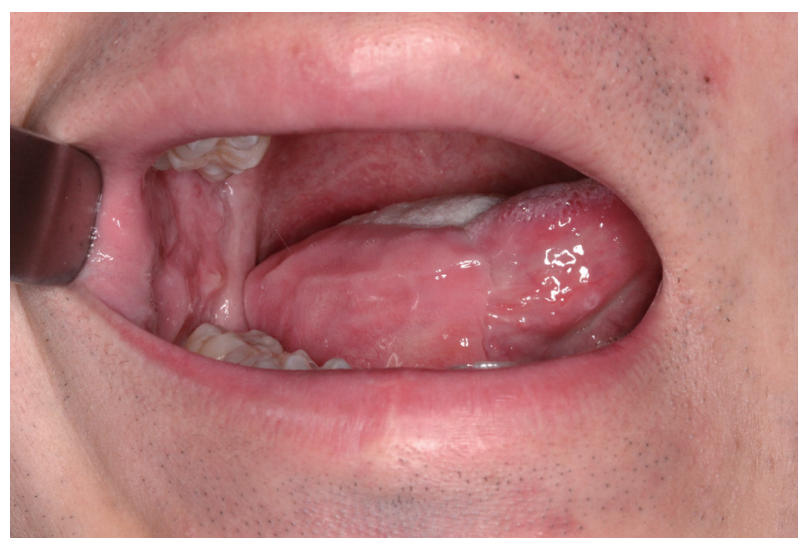

Fig. 4. Photograph taken 3 months after surgery showing a healthy transplanted flap and well-healed donor site. The flap pedicle was sectioned 2 weeks after initial surgery.

부에 부분 괴사가 발생하였으나, 추가적인 치료 없이 저절로 치유되었으며, 피판의 완전 괴사가 발생한 경우는 1 예도 없었 다. 수술 후 2예(13.3\%)에서는 경도의 개구장애가 발생하였으 나 중등도 이상의 개구장애를 보이는 경우는 없었으며, 협교 련 비대칭은 1예도 발생하지 않았다(Table 3, Fig. 4).

\section{고 찰}

저자들은 이번 연구를 통해 구강설암 수술 후 발생한 중등 도의 구강 결손에 있어 Bozola 피판이라는 비교적 간단하면 서도 안전한 술식을 이용하여 적절한 구강 재건이 가능함을 확인할 수 있었다.

피판 거상에 걸리는 평균 시간은 25.3 분(20 35분)으로, Ferrari 등이의 연구에서 20 40분가량으로 보고된 결과와 유 사한 결과를 보였다. 이러한 짧은 피판 거상 시간은 유리 피판 의 경우와 비교하여서는 물론이고, 설골하 피판(infrahyoid flap)이나 턱밑 피판(submental flap)과 같은 중등도 크기의 구강 재건에 이용될 수 있는 다른 국소 피판에 비하여서도 다 소 짧은 것인데, 이는 Bozola 피판술이 유리 피판술과 달리 복잡한 미세혈관 수술법을 필요로 하지 않고, 결손부와 공여 부가 모두 구강 내에 있어 수술 범위(operation field)가 크지 않다는 점 때문일 것으로 생각된다. ${ }^{9.15)}$ 이러한 짧은 피판 거 상 시간은 전체 수술 시간을 단축시켜 고령이거나 기저질환 이 많아 장시간의 전신마취에 대한 부담이 있는 환자들에게 도 적용할 수 있다는 장점이 될 것으로 생각된다.

이번 연구에서 결손부의 평균 크기는 5.5(4.0 6.5 cm)×4.1 $\mathrm{cm}(3.0 \sim 5.0 \mathrm{~cm})$ 였고, 피판의 평균 크기는 5.2(4.0 6.0 cm)× $3.4 \mathrm{~cm}(3.0 \sim 4.5 \mathrm{~cm})$ 로 과교정 없이 피판의 크기를 도안하였 다. 근막 유리 피판을 사용하는 경우 장기적으로 피판의 구축 이 발생함을 고려하여 재건 시 20 30\%가량의 과교정이 필요
한데, ${ }^{16,17)}$ 협부 점막 피판의 경우 점막의 특성상 이식 후 구축 이 거의 생기지 않고 오히려 그 면적이 다소 확장되는 결과를 보이는 것으로 알려져 있으며, ${ }^{18,19)}$ 설사 구축이 발생한다 하 더라도 협부 점막의 경우 최대 $30 \%$ 가량 늘어날 수 있는 탄 력성과 유연성을 가지고 있기 때문에 어느 정도의 구축은 이 러한 점막의 탄력성으로 보상될 수 있는 여지가 크다. ${ }^{20)}$ 또한 이러한 점막의 탄력성과 유연성은 혀와 같이 조음 및 연하 작 용시 역동적 움직임을 필요로 하는 기관에 있어 술 후 기능 을 최대한 보존하는 데 큰 도움이 될 것으로 사료된다. ${ }^{13)}$

이번 연구에서 한가지 주목할 만한 점은 수술 중 혈관경을 확인하지 못한 3예(20.0\%)에서도 모두 특별한 문제 없이 피 판이 잘 생존했다는 것이다. 이는 Bozola 피판의 안정성을 다 시 한번 보여 주는 좋은 예로, 협부 동맥을 직접 시야에서 확 인하지 않더라도 표준화된 수술 술기에 따라 해당 혈관이 존 재하는 조직의 층(tissue plane)을 포함하여 피판을 거상한 다면 피판의 혈류를 안전하게 보존할 수 있음을 시사하는 소 견이라 할 수 있다. 또한 고식적인 Bozola 피판의 경우 후방 에 기저를 둔 국소 축성 피판이기 때문에 도서형 피판과는 달리 전체 협부와 연결되어 있는 후방 점막이 존재하여 추가 적인 혈류 공급에 도움이 되었을 것으로 생각된다.

피판을 거상한 후 발생하는 협부의 공여부 결손은 대부분 의 경우 일차 봉합이 가능하여 공여부 결손 역시 어렵지 않게 해결할 수 있었으며, 이와 관련된 합병증 역시 경한 개구장애 이외에는 특별히 발생하지 않았다. Bozola 피판 후 개구장애 가 발생하는 원인은 피판을 거상한 후 공여부에 발생하는 협 부 반흔 때문인데 이것은 공여부의 결손 크기와 상관관계가 있어 피판의 폭이 $3.0 \sim 3.5 \mathrm{~cm}$ 이하인 경우는 일반적으로 공 여부의 일차 봉합이 가능한 것으로 알려져 있으며, 본 연구 에서 다룬 중등도 결손에 대한 재건의 경우에 있어서도 이에 부합하는 결과를 보였다. ${ }^{12,21)}$

본 연구의 15명 중 10명(66.7\%)에서는 피판경이 치아에 씹 히거나 보철 사용에 장애가 되어 수술 2 3주 후 추가적인 피 판경 절단이 필요하였다. Bozola 피판의 피판경 절단은 대부 분의 경우에 있어 국소마취하에 10 분 이내로 시행할 수 있으 나, 통증에 민감하거나 추가적인 피판의 손질이 필요한 일부 환자에서는 전신마취가 필요하기도 하다. 이처럼 점막 피판 경의 존재는 앞서 언급한 안정적인 혈류 공급에 도움이 될 수 있겠으나, 피판경 절단이 필요한 경우 그에 따른 환자의 불편감, 재입원, 그리고 이차 수술에 따르는 추가적인 비용 등은 Bozola 피판의 단점 중 하나로 생각된다. 또한 Bozola 피판은 거상 가능한 최대 크기가 약 $7 \times 5 \mathrm{~cm}$ 정도로 제한되 어 있어 결손의 크기가 큰 경우에는 재건을 위한 충분한 부 피를 제공하기 어려우며, 피판의 회전점(pivot point)이 후방 
에 있어 혀의 전방부까지 도달하기에는 짧다는 단점이 있 다. ${ }^{10,22)}$ 따라서 일반적으로 혀의 절반 이상이 제거되어 결손 크기가 중등도 이상으로 큰 경우나 혀의 전방부 재건이 필요 한 경우 등에 있어서는, 유리 피판 등의 다른 재건 방법이 우 선 고려되어야 할 것으로 생각된다. 참고로 본 연구에서 국소 적으로 다소 진행되었다고 볼 수 있는 $\mathrm{T} 3$ 병기를 갖는 환자 도 3 명이 포함되었는데, 이들은 종양 병기가 T3 이기는 하였 지만 종양 장축의 크기가 $4.1 \sim 4.5 \mathrm{~cm}$ 인 초기 $\mathrm{T} 3$ 환자들로 모 두 혀 반절제술(hemiglossectomy)이 시행되었으며, 술 후 결 손 부위의 크기가 6.5 7 cm 내외였기 때문에 Bozola 피판으 로도 재건이 가능한 경우였다. 하지만 혀 반절제술이라 하더 라도 결손 부위의 크기가 $7 \mathrm{~cm}$ 보다 큰 경우나 아전 절제술 (near total glossectomy)과 같이 보다 넓은 범위의 수술이 이 루어진 경우에는 Bozola 피판으로는 충분한 부피를 제공하 기 어려우며, 따라서 유리 피판을 사용하는 것이 보다 적절할 것으로 생각된다.

이번 연구의 가장 큰 제한점은 대상 환자가 15 명으로 적으 며, 대상 환자군을 일차 봉합법이나 유리 피판술과 같은 다 른 재건 방법과 직접 비교 분석하지 못했다는 점이다. 유리 피판은 표면적이 넓으면서 얇고 유연해 다양한 모양과 형태 를 재건할 수 있다는 점에서 큰 범위의 구강 결손 부위에 있 어 가장 좋은 방법 중 하나이다. ${ }^{23)}$ 하지만 피판의 부피가 크 고 탄력성이 없어 이식 후 남아 있는 구강설의 움직임을 방해 하기 때문에 결손의 크기가 크지 않은 경우에 있어서는 오히 려 술 후 기능을 저해할 수 있으며, 실제 T3 구강설암이나 혀 반절제술이 시행된 경우를 대상으로 한 연구에서 유리 피판 에 비해 일차 봉합이 보다 나은 조음과 연하 기능을 보이기도 하였다. ${ }^{24,25)}$ 하지만 일차 봉합의 경우 일반적으로 구강설의 $1 / 4 \sim 1 / 3$ 가량의 결손에서는 적용될 수 있으나, 결손 부위가 그보다 큰 경우에는 오히려 반흔에 의한 구축 발생 및 연하 작용에 필요한 충분한 부피 부족으로 만족스러운 결과를 기 대할 수 없다. ${ }^{25)}$ Bozola 피판의 경우 이와 같이 일차 봉합을 하기에는 다소 크기가 큰 중등도 크기의 구강 결손에 가장 적합한 피판으로, 유리 피판과 비교하여서는 그 술기의 간단 함과 근점막 피판이 갖는 특유의 탄력성이 이 피판이 갖는 가장 큰 장점일 것으로 생각된다. 향후 이와 같이 일차 봉합 이나 유리 피판, 그리고 Bozola 피판 등의 장단점을 고려하 여 중등도의 구강 결손을 갖는 환자들을 대상으로 한 각 방 법들 간의 비교 연구가 필요할 것으로 생각된다.

결론적으로 본 연구를 통해 설암 환자에서 Bozola 피판을 이용한 중등도 구강 결손의 재건은 비교적 간단하면서도 심 각한 부작용 없이 높은 성공률을 갖는 효과적인 방법임을 확 인할 수 있었다. 이번 연구를 바탕으로 Bozola 피판이 미세
혈관 수술에 익숙하지 않은 많은 두경부 외과의에게 구강 재 건을 위한 좋은 방법 중 하나로 사용될 수 있기를 기대하는 바이다.

\section{REFERENCES}

1) Adelstein D, Gillison ML, Pfister DG, Spencer S, Adkins D, Brizel DM, et al. NCCN guidelines insights: head and neck cancers, version 2.2017. J Natl Compr Canc Netw 2017;15(6):761-70.

2) Kim JW, Choi EC, Cha IH, Kim YH, Kim YM, Shin JW, et al. Postoperative assessment of speech and swallowing functions in oral tongue cancer. Korean J Otorhinolaryngol-Head Neck Surg 2004;47(4):340-8.

3) Amit M, Na'ara S, Leider-Trejo L, Akrish S, Cohen JT, Billan S, et al. Improving the rate of negative margins after surgery for oral cavity squamous cell carcinoma: a prospective randomized controlled study. Head Neck 2016;38 Suppl 1:E1803-9.

4) Varvares MA, Poti S, Kenyon B, Christopher K, Walker RJ. Surgical margins and primary site resection in achieving local control in oral cancer resections. Laryngoscope 2015;125(10):2298-307.

5) Woo SH, Jeong HS, Kim JP, Park JJ, Ryu J, Baek CH. Buccinator myomucosal flap for reconstruction of glossectomy defects. Otolaryngol Head Neck Surg 2013;149(2):226-31.

6) Miller MJ, Reece GP, Marchi M, Baldwin BJ. Lateral thigh free flap in head and neck reconstruction. Plast Reconstr Surg 1995;96(2): $334-40$.

7) Urken ML, Weinberg H, Buchbinder D, Moscoso JF, Lawson W, Catalano PJ, et al. Microvascular free flaps in head and neck reconstruction: report of 200 cases and review of complications. Arch Otolaryngol Head Neck Surg 1994;120(6):633-40.

8) Lim YS, Oh JK, Kim JT. Intraoral reconstruction with buccinator myomucosal flap. J Korean Soc Plast Reconstr Surg 2004;31(6): $800-4$.

9) Bianchi B, Ferri A, Ferrari S, Copelli C, Sesenna E. Myomucosal cheek flaps: applications in intraoral reconstruction using three different techniques. Oral Surg Oral Med Oral Pathol Oral Radiol Endod 2009;108(3):353-9.

10) Ferrari S, Copelli C, Bianchi B, Ferri A, Sesenna E. The Bozola flap in oral cavity reconstruction. Oral Oncol 2012;48(4):379-82.

11) Bozola AR, Gasques JA, Carriquiry CE, Cardoso de Oliveira M. The buccinator musculomucosal flap: anatomic study and clinical application. Plast Reconstr Surg 1989;84(2):250-7.

12) Ayad T, Kolb F, De Monés E, Mamelle G, Temam S. Reconstruction of floor of mouth defects by the facial artery musculo-mucosal flap following cancer ablation. Head Neck 2008;30(4):437-45.

13) Zhao Z, Zhang Z, Li Y, Li S, Xiao S, Fan X, et al. The buccinator musculomucosal island flap for partial tongue reconstruction. J Am Coll Surg 2003;196(5):753-60.

14) Pribaz J, Stephens W, Crespo L, Gifford G. A new intraoral flap: facial artery musculomucosal (FAMM) flap. Plast Reconstr Surg 1992;90(3):421-9.

15) Patel UA, Hartig GK, Hanasono MM, Lin DT, Richmon JD. Locoregional flaps for oral cavity reconstruction: a review of modern options. Otolaryngol Head Neck Surg 2017;157(2):201-9.

16) Joo YH, Hwang SH, Park JO, Cho KJ, Kim MS. Functional outcome after partial glossectomy with reconstruction using radial forearm free flap. Auris Nasus Larynx 2013;40(3):303-7.

17) Kimata Y, Sakuraba M, Hishinuma S, Ebihara S, Hayashi R, Asakage $\mathrm{T}$, et al. Analysis of the relations between the shape of the reconstructed tongue and postoperative functions after subtotal or total glossectomy. Laryngoscope 2003;113(5):905-9.

18) Massarelli O, Baj A, Gobbi R, Soma D, Marelli S, De Riu G, et al. Cheek mucosa: a versatile donor site of myomucosal flaps. Technical 
and functional considerations. Head Neck 2013;35(1):109-17.

19) Ferrari S, Balestreri A, Bianchi B, Multinu A, Ferri A, Sesenna E. Buccinator myomucosal island flap for reconstruction of the floor of the mouth. J Oral Maxillofac Surg 2008;66(2):394-400.

20) Tsai PT, Shieh YS, Wu CT, Lee SP, Chen YW. Buccal mucosa elasticity influences surgical margin determination in buccal carcinoma resection. J Oral Maxillofac Surg 2016;74(9):1900.e1-7.

21) Ahn D, Lee GJ, Sohn JH. Reconstruction of oral cavity defect using versatile buccinator myomucosal flaps in the treatment of cT2-3, N0 oral cavity squamous cell carcinoma: feasibility, morbidity, and functional/oncological outcomes. Oral Oncol 2017;75:95-9.

22) Van Lierop AC, Fegan JJ. Buccinator myomucosal flap: clinical results and revies of anatomy, surgical technique and applications. J Laryngol
Otol 2008;122(2):181-7.

23) de Vicente JC, de Villalaín L, Torre A, Peña I. Microvascular free tissue transfer for tongue reconstruction after hemiglossectomy: a functional assessment of radial forearm versus anterolateral thigh flap. J Oral Maxillofac Surg 2008;66(11):2270-5.

24) Canis M, Weiss BG, Ihler F, Hummers-Pradier E, Matthias C, Wolff HA. Quality of life in patients after resection of $\mathrm{pT} 3$ lateral tongue carcinoma: microvascular reconstruction versus primary closure. Head Neck 2016;38(1):89-94.

25) Hsiao HT, Leu YS, Lin CC. Primary closure versus radial forearm flap reconstruction after hemiglossectomy: functional assessment of swallowing and speech. Ann Plast Surg 2002;49(6):612-6. 